\title{
11 Moral Skepticism, Fictionalism, and Insulation
}

\author{
Diego E. Machuca
}

\section{Introduction}

In one of his now classic articles on skepticism, Myles Burnyeat (1997 [1984]) claims that a key difference between ancient and contemporary skeptics is that the latter take ordinary beliefs and philosophical doubt to be insulated from each other: one's ordinary beliefs about a given issue are unaffected by one's skepticism about that issue, and vice versa. ${ }^{1}$ Given the theme of the present volume, the focus of this essay will be the relation between moral skepticism and first-order moral beliefs. Specifically, I will examine in what way first-order moral beliefs could be deemed to be insulated from second-order views that deny, or recommend suspension of judgment about, their truth or their epistemic justification. I am thus interested in only one of the directions in which insulation supposedly works.

The topic of moral insulation is related to a distinction commonly drawn between moral error theorists in relation to the attitude they should adopt towards ordinary moral thought and discourse, namely, that between moral abolitionists (or eliminativists) and moral fictionalists. Moral abolitionists maintain that moral error theorists should do away with first-order moral thought and discourse altogether: they should stop thinking according to moral categories and using moral language when talking with those who believe in the objectivity of morality. The reason typically adduced for the abolitionist recommendation is pragmatic: moralizing generates more personal and social costs than benefits. But one could also wonder whether the abolition of first-order moral thought and discourse is not logically or epistemically required by the eliminativists' moral anti-realism. ${ }^{2}$ According to moral fictionalists, by contrast, given that morality produces many practical benefits (e.g., personal happiness or political stability), moral error theorists will be better off if they continue to make first-order moral utterances and have first-order moral thoughts, while at the same time refraining from asserting such utterances and believing such thoughts. When immersed in the moral fiction, the fictionalist is diverted from his moral skepticism and therefore acts as if he really believes in morality. But if pressed in a reflexive or critical context, he will recognize that it is nothing more than a fiction. 


\section{Diego E. Machuca}

This incomplete description of moral fictionalism corresponds to the revolutionary kind, which is the fictionalist stance most commonly discussed in the literature and the one that is relevant to the topic of moral insulation. Whenever I speak of moral fictionalism, I will be specifically referring to revolutionary fictionalism. Although I will also take into account other alternatives available to the moral skeptic, my primary focus will be on fictionalism both because it has been endorsed by some of the most prominent contemporary moral skeptics, and because, in recommending that firstorder moral thought and discourse be preserved, the moral fictionalist may be taken to believe that some kind of insulation is possible.

The aim of this essay is threefold. First, to assess whether the view that first-order moral beliefs are insulated from moral skepticism is defensible. Second, to examine whether a moral skeptic who adopts moral fictionalism can coherently hold that his first-order moral beliefs are unaffected by his skepticism about their truth or their epistemic justification. And third, to determine whether contemporary moral skeptics are in general committed to there being insulation between first- and second-order views.

I will begin by analyzing the notion of insulation: after presenting Burnyeat's treatment of it, I will distinguish between three main types of insulation (Section 2). I will then examine J. L. Mackie's stance on the phenomenon of insulation and his pragmatic conception of morality. In so doing, I will assess the plausibility of two of the three main types of insulation (Section 3). The reason for focusing on Mackie is not only that he is probably the best known and most important contemporary moral skeptic, but above all because in his Ethics one detects an illuminating tension between insulation and continuity between levels. Next, I will present moral fictionalism in more detail and consider whether any of the kinds of insulation distinguished in Section 2 is compatible with the adoption of a fictionalist stance. I will also compare moral fictionalism with a position known as "moral conservationism" (Section 4). I will close by summarizing the results of the examination of the above issues (Section 5).

Before getting down to business, I should remark that I will be concerned primarily with the error-theoretic form of moral skepticism-which claims that all first-order moral judgments are either false or neither true nor false because the objective moral facts or properties they purport to describe do not exist. The reason is that it is mainly moral error theorists who have claimed that first-order moral beliefs are insulated from moral skepticism, and who have embraced moral fictionalism. Still, I will also consider epistemological varieties of moral skepticism, namely, nihilistic epistemological skepticism-which asserts either that moral beliefs are epistemically unjustified or that moral knowledge is impossible-and Pyrrhonian skepticism-which consists in suspending judgment about whether moral beliefs are epistemically justified and about whether moral knowledge is possible. 


\section{The Notion of Insulation}

Burnyeat opens his essay on the phenomenon of insulation thus:

Nowadays, if a philosopher finds he cannot answer the philosophical question 'What is time?' or 'Is time real?', he applies for a research grant to work on the problem during next year's sabbatical. He does not suppose that the arrival of next year is actually in doubt. Alternatively, he may agree that any puzzlement about the nature of time, or any argument for doubting the reality of time, is in fact a puzzlement about, or an argument for doubting, the truth of the proposition that next year's sabbatical will come, but contend that this is of course a strictly theoretical or philosophical worry, not a worry that needs to be reckoned with in the ordinary business of life. Either way he insulates his ordinary first order judgements from the effects of his philosophizing.

(1997: 92)

Hardly anyone will deny that the phenomenon of insulation as depicted in this passage is widespread in present-day philosophy. This may be nothing more than the result of the fact that today philosophy is not normally conceived of as consisting in theoretical discussions leading to the discovery of the correct way of life, as used to be the case in antiquity. Be that as it may, the phenomenon of insulation is found not only among those academics engaged exclusively in the history of the discipline or the exegesis of philosophical texts-not to mention those who are mere 'doxographers'-but also among those engaged in so-called systematic philosophy. Take contemporary epistemological discussions of skepticism, which are in general characterized by a purely methodological use of skeptical arguments. It may be argued that, given that the great majority of contemporary epistemologists believe that skeptical arguments are unsound, the question of whether their ordinary beliefs are insulated from the conclusions of those arguments does not arise. Nevertheless, they recognize both the apparent plausibility of skeptical arguments (they are valid and their premises are intuitively compelling) and the difficulty in determining where those arguments go wrong - in fact, there is considerable disagreement about where exactly they go wrong. This recognition, however, has no effects whatsoever on their ordinary beliefs, which is seemingly due to the phenomenon of insulation. It is interesting to note that, if our first-order beliefs could not be affected by the conclusions of sound skeptical arguments, then pragmatic responses to skepticism would not make much sense, for in such a case skepticism would not really represent a threat to the attainment of those goals we take to be crucial to our lives.

As regards moral skepticism, it is worth noting that, whereas few philosophers have in actual fact doubted or denied the reality of time or the existence of the external world or the possibility of having knowledge of 


\section{Diego E. Machuca}

the world outside us, quite a few have doubted or denied the existence of objective moral facts or the epistemic justification of moral beliefs or the possibility of having knowledge of the moral realm. Moral insulation thus has the significance that, if it were a common phenomenon, it would present us with a stronger and clearer case than those found in other areas inasmuch as there would be quite a number of real skeptics whose first-order moral beliefs would not be infected by the second-order stances they adopt.

Returning to Burnyeat, he distinguishes two kinds of insulation: (i) insulation by subject matter or content (1997: 98-101, 110, 123), and (ii) insulation by level (1997: 122-123). Both types of insulation are discussed in connection with the debate about the scope of Sextus Empiricus's Pyrrhonism, namely, whether suspension of judgment is restricted to theoretical beliefs or extends also to ordinary or commonsense beliefs. In the case of insulation of type (i), commonsense beliefs are insulated from skepticism in that the latter targets a subject matter or a range of propositions with which ordinary people are not concerned in daily life. Insulation of type (ii) occurs when there are two distinct ways of understanding the very same proposition, namely, the ordinary way and the philosophical way. The skeptic does not target the plain man's knowledge claims, which are acceptable in the context of daily life, but only the philosophical claims to absolute knowledge of things as they are in themselves. Burnyeat does not refer to the relation between the two kinds of insulation, but it is clear that insulation by level is incompatible with insulation by subject matter in that, in the former, the philosopher is talking about the very same things as the ordinary man, but claims to possess a deeper understanding of them. Although the philosopher does not theorize about issues or problems that have nothing to do with the affairs of everyday life, ordinary beliefs about certain matters are unaffected by his theoretical views about those same matters. Insulation by content is uninteresting inasmuch as, if first-order beliefs are about matters different from those to which second-order views refer, then it is no mystery why the former are unaffected by the latter. I will therefore focus on insulation by level.

I think that the question of insulation by level should be approached by distinguishing between three main kinds of insulation: logical, epistemic, and psychological. I will describe each in relation to moral insulation. Logical insulation occurs if, from the truth or falsity of moral skepticism, one cannot logically infer the truth or falsity of first-order moral beliefs. Epistemic insulation occurs if knowing or justifiably believing that there are no moral facts or that there is no moral knowledge or no epistemically justified moral belief, or suspending judgment about such issues, does not imply that one should stop holding beliefs about the objective rightness or wrongness of certain actions. Psychological insulation occurs if, even though there is no logical or epistemic insulation, we are as a matter of fact hardwired in such a way that, even if we adopt moral skepticism, either we cannot belp holding first-order moral beliefs, or we may 
continue to hold such beliefs in case doing so turns out to be beneficial. Even though moral skepticism does in principle or in theory affect our first-order moral beliefs, in practice or in fact those beliefs either cannot but remain untouched or may become untouched by moral skepticism on account of our psychological makeup-perhaps the process of evolution has designed the human brain to engage in moral judgment. ${ }^{3}$ Given this disjunctive characterization of psychological insulation, I distinguish between 'extreme psychological insulation' and 'mild psychological insulation'. Whereas extreme psychological insulation would be something that happens to us, mild psychological insulation would be the result of a decision we make for pragmatic reasons. One could perhaps further discriminate between two kinds of mild psychological insulation: one's first-order moral beliefs may become unaffected by moral skepticism so long as one keeps performing a certain mental action, or they may become unaffected by moral skepticism once and for all as soon as one performs such an action. Let me finally note that I will use the term 'insulator' to designate someone who thinks that his skepticism cannot affect his firstorder beliefs, or who decides to shield his first-order beliefs from his skepticism for pragmatic reasons. ${ }^{4}$

\section{Is Mackie an Insulator?}

If you have perused Mackie's Ethics, you probably got the impression that something odd is going on: in the first part of a book someone proposes and defends a skeptical view according to which all substantive moral judgments are false because the objective moral facts they purport to describe do not exist, only to make in the second part claims that appear to express substantive moral judgments. The impression of oddness can be mitigated if Mackie thinks that there is no continuity between levels, and hence that moral skepticism-and metaethical views in general—cannot affect our first-order moral judgments. In fact, at times he explicitly embraces such a position, as when he distinguishes between first- and second-order moral skepticism. With regard to the former, he points out:

'[M]oral scepticism' might also be used as a name for either of two first order views, or perhaps for an incoherent mixture of the two. A moral sceptic might be the sort of person who says 'All this talk of morality is tripe,' who rejects morality and will take no notice of it. Such a person may be literally rejecting all moral judgements; he is more likely to be making moral judgements of his own, expressing a positive moral condemnation of all that conventionally passes for morality; or he may be confusing these two logically incompatible views, and saying that he rejects all morality, while he is in fact rejecting only a particular morality that is current in the society in which he has grown up.

(Mackie 1977: 16) 


\section{Diego E. Machuca}

So Mackie distinguishes between three first-order skeptical views: $(i)$ the rejection of all morality, (ii) the rejection of all conventional morality on the basis of a substantive moral judgment, and (iii) the incoherent rejection, on moral grounds, of all morality. The first of these is the most interesting for the topic of insulation, but before saying something about this, it must be observed that Mackie regards first- and second-order skeptical views as entirely separate from each other:

These first and second order views are not merely distinct but completely independent: one could be a second order moral sceptic without being a first order one, or again the other way round. A man could hold strong moral views, and indeed ones whose content was thoroughly conventional, while believing that they were simply attitudes and policies with regard to conduct that he and other people held. Conversely, a man could reject all established morality while believing it to be an objective truth that it was evil or corrupt.

It is plain that someone can coherently assert that morality as conventionally conceived is to be rejected while holding the second-order view that there are objective moral truths. The reason is that his first-order skeptical assertion is based on the substantive moral judgment that such morality is evil or corrupt (first-order moral skepticism of type (ii) above), and that this judgment in turn rests on that second-order view. Now, whereas there is no incoherence in this first case, how can someone retain strong moral views after denying that there are objective moral truths? In other words, how can someone keep holding beliefs about facts and properties that he claims do not exist, that are not part of, as Mackie likes to say, "the fabric of the world" (1977: 15, 22-24)? If first-order moral skepticism of type (ii) is independent of second-order moral skepticism because the former is based on a substantive moral judgment that in turn rests on a metaethical realist stance, how is it possible that substantive moral judgments like that one are not undermined by the adoption of a second-order skepticism that is the very denial of that realist stance?

Despite presenting a threefold taxonomy of first-order moral skepticisms in the first quoted passage, in the second Mackie only considers firstorder moral skepticism of type (ii). Regarding first-order moral skepticism of type (iii), it is interesting that he rightly regards as incoherent the view that rejects, on moral grounds, all substantive moral judgments, but does not regard in the same way the view that maintains that such judgments are insulated from second-order skepticism. The reason is clearly that the first case concerns a relation between two first-order views, whereas the second case concerns a relation between a first- and a second-order view, which he regards as completely independent of each other. What about first-order moral skepticism of type (i)? From Mackie's formulation of it, 
such skepticism corresponds to what is commonly called "moral nihilism," which is the first-order view that nothing is morally good or bad, right or wrong. It is considered a first-order view because it is expressed in the object language, which in the present case is the ordinary language used to make moral claims about 'objects' that exist in the world (actions, practices, events, persons, etc.). As I said above, this first-order moral skepticism is the most interesting one for the topic of insulation. The reason is that it might be argued that someone who rejects all morality or all substantive moral judgments as nonsense can do so only on the basis of a second-order moral skepticism, and hence that there is no insulation between his first- and second-order views. This seems to be precisely what distinguishes first-order moral skepticism of type (i) from that of type (ii): the latter type is based on a substantive moral judgment that in turn rests on a second-order realist stance, whereas the former type is based on a second-order moral skepticism that calls into question the objective truth of all substantive moral judgments. However, it is possible for someone to deny that anything is morally right or wrong without basing his view on some metaethical argument or without being able to defend his view when challenged by an opponent. Hence, endorsement of moral nihilism does not necessarily imply endorsement of second-order skepticism because the latter view is not necessarily endorsed on the basis of the former. This does not mean, however, that the reverse is true, for it is highly implausible that an error theorist, despite his considered ontological moral skepticism, is entitled to claim not to be a moral nihilist, i.e., entitled to continue to hold the belief that certain acts are morally right or wrong. The same goes for epistemological moral skepticism. Take Pyrrhonian moral skepticism, for example. One could suspend judgment about whether anything is morally right or wrong on the basis of no metaethical argument or without being able to defend his suspension if challenged. But it is highly implausible that someone who suspends judgment about the epistemic justification of both first-order moral beliefs and ethical theories is entitled not to suspend judgment about whether anything is morally right or wrong.

Mackie, then, takes first-order moral beliefs to be unaffected by secondorder moral skepticism. Given the threefold distinction of types of moral insulation proposed in Section 2, what kind of insulator is he? Mackie explicitly opts for logical insulation in the following passage:

[R. M. Hare] sums up his case thus: 'Think of one world into whose fabric values are objectively built; and think of another in which those values have been annihilated. And remember that in both worlds the people in them go on being concerned about the same things-there is no difference in the "subjective" concern which people have for things, only in their "objective" value. Now I ask, "What is the difference between the states of affairs in these two worlds?" Can any answer be given except "None whatever"?" 
Now it is quite true that it is logically possible that the subjective concern, the activity of valuing or of thinking things wrong, should go on in just the same way whether there are objective values or not. But to say this is only to reiterate that there is a logical distinction between first and second order ethics: first order judgements are not necessarily affected by the truth or falsity of a second order view. But it does not follow, and it is not true, that there is no difference whatever between these two worlds. In the one there is something that backs up and validates some of the subjective concern which people have for things, in the other there is not.

(1977: 21-22)

According to Mackie, then, even though in the moral skeptical world firstorder moral beliefs are not epistemically justified because there are no objective values that "back up" and "validate" them, the moral skeptic can nonetheless retain those beliefs. For Mackie takes the subjective concern people have for things to consist not only in valuing things-which could be interpreted as merely expressing personal preferences-but also in thinking they are right or wrong and in making first-order moral judgments. And he explicitly maintains that there is a logical distinction between the two levels: our first-order moral judgments are not necessarily affected by the truth or falsity of moral skepticism, which is to be interpreted in the sense that their truth or falsity may be impervious to that of moral skepticism. Note also that, in making that logical distinction, Mackie is reiterating the point made when distinguishing earlier between first- and second-order skepticism, which means that thinking and judging that certain things are morally right or wrong consists in holding strong moral views. In sum, for Mackie there is a crucial ontological difference between the two worlds that has epistemic consequences in that, in the moral skeptic's world, the first-order moral claims are not backed up or validated by objective moral values. But such consequences do not extend so far as to prevent us from continuing to believe that things are morally right or wrong and to make first-order moral judgments expressing those beliefs. Given that first-order moral beliefs and judgments can be preserved, the logical insulation defended by Mackie has epistemic effects, and hence entails an epistemic insulation: knowing or justifiably believing that there are no mind-independent moral values does not imply that one should stop holding beliefs about the objective rightness or wrongness of certain actions. ${ }^{5}$

Another contemporary moral skeptic who explicitly endorses the view that first-order moral beliefs are insulated from second-order skepticism is Walter Sinnott-Armstrong-who, unlike Mackie, is not an error theorist, but an epistemological skeptic. For he maintains that "second-order beliefs about the epistemic status of moral beliefs cannot force us to give up the moral beliefs that we need to live well" (2006: viii). Moreover, he claims that moral skeptics 
can hold substantive moral beliefs just as strongly as non-skeptics. Their substantive moral beliefs can be common and plausible ones. Moral skeptics can even believe that their moral beliefs are true by virtue of corresponding to an independent moral reality. All that moral skeptics deny is that their or anyone's moral beliefs are justified or known. . . . This meta-ethical position about the epistemic status of moral beliefs need not trickle down and infect anyone's substantive moral beliefs or actions.

(2006: 13-14)

Likewise, he points out: "I am not a moral nihilist. I believe that many acts are morally wrong. I think that my positive moral beliefs are true and correspond to moral facts" (2006: 58). My reason for quoting these passages is that Sinnott-Armstrong is even clearer and bolder than Mackie in his endorsement of the view that first-order moral beliefs are logically and epistemically immune from second-order moral skepticism. And like Mackie, Sinnott-Armstrong takes it as obvious that there is such insulation between levels-so obvious that it does not need to be argued for.

Notwithstanding this alleged obviousness, I confess that I fail to see the plausibility of logical and epistemic insulation. How is it logically and epistemically possible for someone to deny the "backup" or "validation" of a certain type of judgment while at the same time being entitled to make judgments of that type and to regard them as true? Likewise, how can someone, despite denying that his substantive moral beliefs are epistemically justified or known, hold to them as being true by virtue of their correspondence with objective or mind-independent moral facts? Consider the adoption of an error theory regarding witchcraft or astrology. It seems plain that, from the truth of an error theory about the existence of witches or the influence of the positions and movements of celestial bodies on earthly occurrences and human affairs, one can infer the falsity of a judgment that ascribes magical powers to a given person or of the predictions of today's horoscope. Similarly, one does not seem to be entitled to continue to hold first-order beliefs about witches or astrological matters if one claims to know that there are no witches or that the positions and movements of celestial bodies have no influence on earthly occurrences and human affairs. We can also appreciate how implausible Mackie and Sinnott-Armstrong's view is if we think in terms of defeaters. For it can be argued that S's second-order skeptical view that his first-order moral beliefs are all false or epistemically unjustified serves as a defeater for S's first-order moral beliefs, and hence that $S$ should stop holding them. Suppose that one forms one's beliefs about the temperature in a room at different times by looking at a thermometer on one of the walls. If one comes to believe that the thermometer has always been unreliable, then it seems plain that one's beliefs about the temperature are defeated and that one should therefore stop holding them. Likewise, suppose that one thinks one forms one's first-order moral beliefs via intuition. If one comes to believe that moral intuition is unreliable, then it seems plain that one's first-order 


\section{Diego E. Machuca}

moral beliefs are defeated and that one should therefore stop holding them. If Mackie and Sinnott-Armstrong agreed that in the thermometer case the beliefs about the temperature are defeated and that one should therefore stop holding them, it seems they should agree that in the moral intuition case first-order moral beliefs are likewise defeated and that one should therefore stop holding them. And if they thought that first-order beliefs are defeated and should not therefore be held anymore in the former case but not in the latter, they would bear the burden of explaining why the two cases are different. It might be the case that moral skeptical arguments do not in fact have an impact on our first-order moral beliefs due to some form of psychological insulation, but this is of course different from claiming that they should not, which is what proponents of logical and epistemic forms of insulation, such as Mackie and Sinnott-Armstrong, maintain.

In the passages of Ethics quoted thus far, Mackie explicitly endorses the view that first-order moral beliefs are logically and epistemically insulated from second-order moral skepticism. There are, however, several passages in which he seems to accept that the moral skeptic's second-order stance does have an effect on the first-order level, thus infecting his ordinary moral beliefs. Consider the following:

'Our sense of justice,' whether it is just yours and mine, or that of some much larger group, has no authority over those who dissent from its recommendations or even over us if we are inclined to change our minds. But if there is no objective moral truth to be discovered, is there nothing left to do but to describe our sense of justice?

At least we can look at the matter in another way. Morality is not to be discovered but to be made: we have to decide what moral views to adopt, what moral stands to take. No doubt the conclusions we reach will reflect and reveal our sense of justice, our moral consciousness. ... But that is not the object of the exercise: the object is rather to decide what to do, what to support and what to condemn, what principles of conduct to accept and foster as guiding or controlling our own choices and perhaps those of other people as well.

(1977: 105-106)

[T] he content of the first order moral system is more malleable, more a matter of choice, than utilitarianism, in any form, makes it appear. . . $[\mathrm{T}]$ here is no merit in pretending that our choices are rationally constrained in ways that they are not. We are, then, free to mould or remould our moral system so as better to promote whatever it is that we do value.

It does not follow ... that an individual is free to invent a moral system at will. If a morality is to perform the sort of function described 
in Chapter 5 , it must be adopted socially by a group of people in their dealings with one another.

To say that someone has a right, of whatever sort, is to speak either of or within some legal or moral system: our rejection of objective values carries with it the denial that there are any self-subsistent rights.

Morality as I have described it is concerned particularly with the wellbeing of active, intelligent, participants in a partly competitive life, and the constraints summed up as morality in the narrow sense have been introduced ... as necessary limits on competition for the benefit of all the competitors.

[T] he arguments of the preceding chapters ... show how there can be a secular morality, not indeed as a system of objective values or prescriptions, but rather as something to be made and maintained, and which there is some real point in making.

The rationality of morality ... consists in the fact ... that men need moral rules and principles and dispositions if they are to live together and flourish in communities, and that evolution and social tradition have given them a fairly strong tendency to think in the required ways.

(1977: 228-229)

The idea that morality must be made, invented, or molded rather than discovered is central to Mackie's view, as already indicated in the very subtitle of his 1977 book: Inventing Right and Wrong. What is the status of this morality? Insofar as the error theorist is aware that his own morality has no authority over those who have adopted a different one-given that there is no objective prescriptivity on the basis of which he is entitled to claim that they are required to endorse his own morality-it seems that the first-order moral beliefs that he used to hold before becoming a moral skeptic are indeed affected by his second-order stance. This is why saying that someone has a right makes sense only within a given invented (legal or moral) system: the denial of the existence of objective moral values entails the denial of the existence of self-subsistent rights. The adoption of moral error theory does not therefore leave things as they were: morality as ordinarily understood is undermined or debunked, and so we must make and maintain a new one. If first-order moral beliefs remained intact in the face of moral skepticism, what need would there be for constructing a new firstorder moral system? There are, according to Mackie, restrictions on which 


\section{Diego E. Machuca}

first-order moral system to invent and adopt, but these are pragmatic, not moral, restrictions: the first-order moral system must make it possible to live within a society in a way that benefits all participants; it must provide rules that regulate behavior and govern social interactions in a way that allows everyone to flourish. ${ }^{6}$ One may quite reasonably wonder in what sense we can continue to call such a system a 'moral' one insofar as it merely reflects our preferences, those things that we in fact value, and not objective values, prescriptions, or requirements. Besides the fact that the moral skeptic continues to experience what can be described as moral emotions, the answer seems to lie mainly in the fact that the first-order moral systems of the skeptic and the realist perform a certain function: the commonality is not found in the ontologico-epistemological foundation of their moral systems, but on the personal and social aims they help to achieve. In addition, the skeptic's first-order moral system reflects, just as the realist's, our strong tendency, shaped by evolution and culture, to think according to moral categories. Hence, Mackie's conception of such a first-order moral system is a pragmatic one, which again shows that the undermining or debunking effects of his moral error theory do carry over to the first-order level, infecting ordinary moral beliefs. This exclusively pragmatic conception of morality would dispel the impression of oddness to which I referred at the very beginning of the present section: the second part of Ethics does not propose a first-order moral system that is of the same kind as those targeted by moral error theory. Such a pragmatic conception of morality is incompatible with moral insulation and squares well with moral fictionalism-a stance to be discussed in the next section. In fact, at one point Mackie does talk of morality being a useful fiction: "In so far as the objectification of moral values and obligations is not only a natural but also a useful fiction, it might be thought dangerous, and in any case unnecessary, to expose it as a fiction. This is disputable" (1977: 239). In a later book, while recognizing the significant benefits of morality insofar as it fulfills a social function, Mackie (1980: 154-156) also emphasizes its negative effects, but without going as far as to recommend the adoption of moral abolitionism. It is possible that, in the end, he remained in a state of suspension of judgment about whether morality should be abolished or retained as a fiction.

Before concluding my discussion of Mackie, I would like to mention a peculiar interpretation of his stance on insulation that is suggested by Enoch (2011: 42-43): though Mackie's moral error theory has first-order implications, it does not have discriminating first-order implications. This means that moral error theory establishes that morality is a fiction, but has no implications within that fiction: it does not allow one to make distinctions between claims made within the moral fiction or to settle disputes that arise within it. ${ }^{7}$ This interpretation will not do because it accepts that moral error theory affects all first-order moral judgments inasmuch as these judgments can be made only within the context of the moral fiction. But 
the logical and epistemic insulation that Mackie advocates at certain points (and that Sinnott-Armstrong wholeheartedly embraces) requires more than that: it requires that, despite one's moral skepticism, one can continue to hold beliefs about the objective rightness or wrongness, and not merely the within-the-fiction rightness or wrongness, of certain actions. If ordinary moral discourse loses its claim to moral objectivity, then it is not immune from moral skepticism.

Mackie seems at times to accept that there is continuity between firstand second-order levels-which would explain his pragmatic conception of morality-thereby creating a strong tension with the logical and epistemic insulation he explicitly claims to embrace at other times. If there is indeed such a tension in Mackie, I confess that I do not know how to resolve it or if it can be resolved. But leaving this interpretive issue aside, one of the points I want to make in this essay is that moral insulation is incompatible with certain views commonly adopted by contemporary moral skeptics, and hence that it would be a mistake to affirm that all or most of them are insulators.

\section{Moral Fictionalism and Insulation}

In this section, I will discuss moral fictionalism and one of its competitors. My aim is not to assess their plausibility or to decide between them, but to examine their compatibility with the view that first-order moral beliefs are insulated from moral skepticism. My description of moral fictionalism will be based on the version defended by Richard Joyce, because it is both the best known and the one relevant to the topic at hand. ${ }^{8}$ Remember that whenever I speak of moral fictionalism, I have in mind the revolutionary kind.

What does moral fictionalism consist in? The first thing to say is that the moral fictionalist is a skeptic. To the best of my knowledge, in the metaethical literature moral fictionalism has always been associated with a moral error-theoretic position, but it could in principle be adopted by any moral skeptic-except the moral non-cognitivist, since the moral fictionalist takes the default use of moral language to be assertoric or descriptive. So the moral fictionalist is someone who could in principle be either an ontological or an epistemological moral skeptic: he denies that there are objective moral facts or properties, or denies that we have moral knowledge or justified moral beliefs, or suspends judgment about whether there are objective moral facts or properties and about whether there is such a thing as moral knowledge or justified moral beliefs. In what follows, I will focus for the most part on the moral fictionalist who is an error theorist.

The second aspect of the moral fictionalist's stance to be mentioned concerns his practical attitude towards first-order moral thought and discourse once morality has been debunked - the attitude that defines him as a fictionalist. He maintains that it would be irrational to carry on holding moral beliefs, that it is not psychologically possible to do so, and that, even if it 


\section{Diego E. Machuca}

were psychologically possible, one should not carry on holding them because truth is of instrumental value. Nevertheless, the moral fictionalist does not claim that we should do away with morality altogether, because he believes that morality is useful inasmuch as, by bolstering self-control, it allows us to attain certain personal and social goals. He therefore proposes to preserve first-order moral thought and discourse in a way that does not commit us to error (or lying or self-deception), namely, by having moral thoughts without believing them and by making moral utterances without asserting them, in the same way in which a storyteller thinks about and utters propositions he knows would be false were he to use them to describe, predict, or explain what he takes to be reality. The moral fictionalist mantains that even when moral thoughts are knowingly employed as fictions, they can nevertheless engage our emotions-in the same way in which reading a story or seeing a movie can engage them-and that emotional reactions can influence our motivations to act in ways conducive to attaining desirable ends. So in his daily life the moral fictionalist carries on employing first-order moral discourse as if it were not false, immersing himself in the moral fiction and pretending that it is true. But if pressed in a critical or reflective contexteither by others or by himself-he will immediately step out of the fiction and recognize it as such. It is not that in the ordinary context he stops endorsing his moral skepticism; it is just that he is not attending to it. The moral fictionalist does not affirm that his stance provides all the benefits of a believed morality, but only that, after examining the costs and benefits of his stance and its alternatives, ${ }^{9}$ it is moral fictionalism that seems to get the better results. There is thus a pragmatic reason for the moral fictionalist's decision not to dispense with first-order moral thought and language altogether, and so in a purely instrumental sense, it can be said that he is justified in maintaining the fiction that moral realism is true. ${ }^{10}$

This brief characterization of moral fictionalism makes it clear that the reason why its proponent continues to use first-order moral language is not that he believes that his moral skepticism does not affect first-order moral judgments. Rather, precisely because moral skepticism does have a defeating effect on first-order moral judgments, the moral fictionalist refrains from using moral language in an assertoric or descriptive way. He reasons and acts as though moral judgments were true and as though he held first-order moral beliefs, without losing sight of the fact that this is what he is doing. Hence, moral fictionalism is incompatible with both logical and epistemic forms of insulation. Similarly, if, as a matter of psychological fact, one's first-order moral beliefs cannot but be insulated from one's moral skepticism or if one could insulate them from it in case it turned out that holding such beliefs is beneficial, then there would be no need to pretend to believe in the fiction that certain actions, practices, or events are morally right or wrong in an objective sense. Moral fictionalism is thus also incompatible with both extreme and mild psychological insulation. It could be argued, though, that there is a sense in which the moral 
fictionalist accepts moral insulation: he recognizes that some aspects of morality—namely, moral thoughts and moral emotions-are for the most part immune from moral skepticism. Even though I think this is correct, it should be noted that such a kind of insulation does not leave things entirely as they were: first-order moral beliefs and assertions are done away with on account of the skeptical arguments that undermine their epistemic credentials. The kind of insulation that is intriguing, and on which I focus in this essay, is doxastic insulation, i.e., that of first-order moral beliefs from second-order skepticism. Moral fictionalism is incompatible with any kind of doxastic insulation. Hence, if a moral error theorist adopted moral fictionalism, he could not claim, at the risk of being inconsistent, that his firstorder moral beliefs are insulated from his moral skepticism, for there could not be such separation between the two levels. The tension in Mackie's position to which I called attention at the end of the previous section can now be construed more clearly as a tension between moral insulation and moral fictionalism. Note also that the apparent incongruity between the two parts of Ethics mentioned at the outset of the previous section can be explained either by Mackie's endorsement of logical and epistemic insulation or by his endorsement of moral fictionalism.

To shed more light on moral insulation and its incompatibility with moral fictionalism, one can compare the latter with moral conservationism, a position recently endorsed and defended by Jonas Olson (2014: ch. 9). He proposes it as an alternative available to the moral error theorist that is better than either moral abolitionism or moral fictionalism. Like the moral fictionalist and unlike the moral abolitionist, the moral conservationist thinks that morality is socially useful in that it allows us to prevent and resolve conflicts, regulate interpersonal relations, and counteract limited sympathies. What distinguishes moral conservationism? Olson describes it as the "preservation of ordinary (faulty) moral thought and discourse" (2014: 178). But thus formulated, the view does not clearly differ from moral fictionalism. For the moral fictionalist, too, recommends that we keep employing ordinary moral thought and discourse, albeit not in the same way as they are normally used inasmuch as the ordinary man does believe and assert the moral sentences he utters. We must therefore interpret moral conservationism as the complete preservation of ordinary moral thought and discourse, both regarding the content of moral sentences and the illocutionary force with which they are uttered. Hence, the moral conservationist maintains that we should keep believing and asserting first-order moral sentences even though we know full well that they are all false. One can interpret the moral conservationist as endorsing a restricted form of irrationality: one should keep holding beliefs one knows to be false due to their instrumental valuea paradigmatic case of self-deception.

Olson describes the moral conservationist's attitude as a sort of compartmentalization: "conservationism recommends moral belief in morally engaged and everyday contexts and reserves attendance to the belief that 


\section{Diego E. Machuca}

moral error theory is true to detached and critical contexts, such as the philosophy seminar room" (2014: 192). Olson maintains that this compartmentalization is feasible:

[I]t is a psychologically familiar fact that we sometimes temporarily believe things we, in more reflective and detached contexts, are disposed to disbelieve. In such cases, the more reflective beliefs are suppressed or not attended to. This might be because of emotional engagement, affection, peer pressure, or a combination of these factors. [...]

Something similar might be going on with moral beliefs. The error theorist might say, 'I knew all along there is no such thing as moral wrongness, but hearing on the news about the massacre on civilians, I really believed that what the perpetrators did was wrong; I really believed that the UN ought morally to enforce a cease fire'. [. . .]

[C]ertain actions and events may engage our emotions of anger, empathy, etc., to the effect that it seems to us that the actions are morally wrong and that we virtually cannot help believing that they are morally wrong, no matter how intellectually compelling we find arguments in favour of moral error theory. It appears realistic that in morally engaged and engaging contexts, affective attitudes like anger, admiration, empathy, and the like, tend to silence beliefs that moral error theory is true.

(2014: 192-193)

And in a note he offers two analogies:

Some optical illusions are such that it seems to us that one line is longer than another, even though we know that the lines are of equal length. It seems possible that in unreflective moments we believe, on the basis of how things seem, that one line is longer. [. . .] Many utilitarians who are convinced that their theory is correct and that according to this theory, the bystander ought to push the fat man off the bridge in the famous trolley case ... still feel an intuitive reluctance to make this judgement. (2014: 193, n. 42)

The first thing to note is that the moral fictionalist who is an error theorist, a nihilistic epistemological skeptic, or a Pyrrhonist will not disagree with Olson that certain actions or events still trigger in them both moral thoughts (or 'appearances', as the Pyrrhonist would call them) and emotional reactions. For instance, a Pyrrhonian fictionalist does not express a belief when, in referring to a stick half-submerged in water, he remarks: "It appears to me that the stick is broken." Similarly, when he says "It appears to me that $x$ is morally wrong," he is not expressing a belief about $x$, but only the way he is still affected by $x$ on account of, e.g., his upbringing, education, and life experiences. Olson talks indistinctively, and erroneously, of moral beliefs and what we might call 'moral seemings' or 'moral appearances', which is precisely 
what allows him to use the two analogies. Also, it is clear that the emotions brought about by certain actions or events cause the moral fictionalist to make utterances that express approval or disapproval, and to act accordingly, but there is no reason to assume that, while making such utterances, he believes that their contents describe objective moral facts or properties.

Leaving aside my reservations about Olson's position, what is important for present purposes is that, although he does not refer to insulation as such, it is plain that his moral conservationism is the explicit endorsement of the view that first-order moral beliefs can be shielded from moral error theory. Because holding first-order moral beliefs generates practical benefits, the moral conservationist makes the decision to insulate them from his skepticism. The kind of insulation in question is therefore what I called "mild psychological insulation" in Section 2: the moral conservationist does not claim that first-order moral beliefs are immune from moral error theory, but rather that they can become immune to it if one comes to the conclusion that preserving them is beneficial, and as long as one engages in a process of compartmentalization. ${ }^{11}$ Why is the insulation in question not of the logico-epistemic kind? Because if our first-order moral beliefs were logically or epistemically immune from moral error theory, there would be no need to compartmentalize those beliefs and the belief in the truth of that theory. If in ordinary contexts the moral conservationist should not attend to the conclusions of the sound arguments in favor of moral error theory for pragmatic reasons, it is because such conclusions do have a defeating effect on his first-order moral beliefs. ${ }^{12}$

It could be argued that the apparent incongruity between the two parts of Mackie's Ethics is to be explained by the fact that he endorses moral conservationism. That Mackie is a moral conservationist is suggested by Olson himself, according to whom Mackie could be taken

to be saying that a man can subscribe to both views [that moral discourse is error-ridden and that we can hold strong moral beliefs], but that he cannot attend to both views simultaneously. He must compartmentalize his thoughts and avoid entertaining both thoughts at the same time.

(2014: 41-42, n. 75)

The problem with this interpretation of Mackie's position is simply that, in the passages in which he talks about the lack of continuity between levels, the form of insulation in question is logico-epistemic, not psychological. Even though, like Olson, Mackie thinks that morality is useful in that it serves a social function, pragmatic reasons have nothing to do with his claim that first-order moral beliefs are unaffected by second-order moral skepticism.

Someone might argue that fictionalism actually rests upon a kind of psychological insulation, in a way similar to moral conservationism. For when 
the moral fictionalist is in an ordinary context using moral terms and thinking in accordance with moral concepts, he is in fact insulating his moral discourse and thinking from his moral skepticism. However, even though there seems indeed to be some kind of psychological dissociation at work here, it is clearly not a type of insulation, for the moral fictionalist does not adopt the schizophrenic doxastic attitude of the moral conservationist. There is dissociation inasmuch as the moral fictionalist is not attending to his moral skepticism while immersed in the moral fiction, for this might interfere with his fictive attitude. If, while watching a science fiction movie, I keep telling myself that what I am watching is incredible or highly implausible or absurd, doing so might interfere with my enjoyment of the story being told. But there is no insulation in the moral fictionalist's stance inasmuch as, while immersed in the moral fiction, he does not hold moral beliefs or assert moral utterances because he does not abandon his moral skepticism. Not only does he recognize that the moral fiction is a fiction if asked in the context of a philosophical discussion, but he also does so recognize if asked out of the blue in the context of ordinary life. If, while watching a science fiction movie, I am asked whether I believe that most of the things being depicted are possible, I will immediately reply that of course I do not believe so. Once again, the very formulation of a moral fictionalist stance presupposes that the conclusions of certain metaethical skeptical arguments do affect our first-order moral claims and prevent us from continuing to believe those claims.

\section{Concluding Remarks}

Let me sum up the results obtained in the previous sections. First, in analyzing the notion of insulation, it might be appropriate to distinguish between logical, epistemic, and psychological insulation. Regarding the first two forms of insulation, it is not defensible to claim that first-order beliefs are logically or epistemically insulated from second-order views, because firstorder beliefs can be defeated by second-order views on the basis of higherorder evidence. Psychological insulation, by contrast, seems more plausible inasmuch as, if it occurred, it would be a fact about our psychological makeup: as a matter of psychological fact, certain first-order beliefs either are always impervious to second-order views or may become so in certain circumstances.

Secondly, there is in Mackie, probably the most prominent contemporary moral skeptic, a strong tension between the view that first-order moral beliefs are logically and epistemically insulated from second-order moral skepticism, on the one hand, and the recognition of continuity between levels that leads him to a pragmatic conception of morality, on the other. This tension can be interpreted as a tension between moral insulation and moral fictionalism, which are clearly incompatible. Indeed, given that moral fictionalism maintains that the moral skeptic should proceed as though he believed that 
first-order moral claims are true, moral fictionalists admit that, from the truth of moral skepticism, one can infer the falsity of first-order moral judgments, and that one should stop holding first-order moral beliefs once one becomes a moral skeptic. Consideration of the mild psychological insulation described by the moral conservationist makes such incompatibility clearer as far as this form of insulation is concerned. Note also that examination of moral fictionalism and moral conservationism shows that extreme psychological insulation does not occur inasmuch as proponents of those views are able to abandon their first-order moral beliefs once they realize that these beliefs are defeated by their skepticism. By contrast, one can say that mild psychological insulation does occur if one believes the moral conservationist's report on his experience of self-deception. The immunity conferred by the process of compartmentalization is not attained once and for all, but will be retained as long as the moral conservationist does not attend to his moral skepticism in ordinary contexts. One could hypothesize that those moral skeptics who mistakenly think that their first-order moral beliefs are logically and epistemically immune from their moral skepticism think so at least in part because they experience mild psychological insulation: they are able to insulate their substantive moral beliefs from their skepticism when they recognize their pragmatic value-as we saw, even Sinnott-Armstrong talks about "the moral beliefs that we need to live well."

Finally, it would be a mistake to claim that contemporary moral skeptics are in general committed to the view that there is insulation between their first-order beliefs and their skepticism. The moral fictionalist is clearly not an insulator in any of the senses distinguished-Mackie being a complex and intriguing case-and the mild psychological insulation described by the moral conservationist is not a widespread phenomenon. The moral abolitionist's stance, too, is incompatible with moral insulation: if one can and should abolish morality, then it is not the case that first-order moral beliefs are logically, epistemically, or psychologically insulated from moral skepticism. Note also that moral skeptics who adopted propagandism (on which see notes 9 and 12) or what has recently been called "revolutionary expressivism" (Köhler \& Ridge 2013) would not be insulators either. The propagandist would not try to keep the truth of moral skepticism from the general public if he thought that first-order moral beliefs are unaffected by it. And the revolutionary expressivist who claims that if moral error theory is true, we should become moral expressivists, accepts the moral error theorist's view that ordinary moral claims express beliefs but maintains that they should no longer express beliefs in case the antecedent of the conditional obtains. If first-order moral beliefs were impervious to moral skepticism, there would be no need to adopt an expressivist or non-cognitivist stance. That the view that there is insulation between first-order beliefs and skepticism is not prevalent among contemporary moral skeptics should probably come as no surprise, given that it is most likely the result of the fact that we are talking about real skeptics and not merely philosophers who examine 


\section{Diego E. Machuca}

and discuss skepticism in a detached manner and do not in the end take it seriously. It seems that when skepticism becomes a real option, the view that our first-order beliefs are insulated from it dissipates considerably. ${ }^{13}$

\section{Notes}

1 Burnyeat's thesis is not restricted to a difference between ancient and contemporary skepticism, but refers to a difference between ancient and contemporary philosophy more generally. However, Burnyeat's whole treatment of insulation and all of his examples concern skepticism, and in any case moral skepticism is the topic in which I am interested.

2 To the best of my knowledge, all contemporary moral eliminativists are moral anti-realists: see Hinckfuss (1987), Garner (1994; 2010), Burgess (2010), and Marks (2013). But nothing seems to prevent an epistemological moral skeptic from being a moral eliminativist.

3 What I describe as logical insulation and epistemic insulation may be partially similar to what Bett (1993: 375-377) calls "extreme insulation," while what I describe as psychological insulation may be somewhat close to what he calls "practical insulation" (1993: 374-375, 377). Also, while the first two kinds of insulation I distinguish may be similar to what Wong (2002: 350) defines as the insulation that concerns "a certain relation between scepticism and common sense," the third kind of insulation I identify clearly corresponds to what he characterizes as the insulation that concerns "a certain relation between the sceptic's beliefs about the world and his sceptical belief" (2002: 350).

4 Let me make an idiomatic digression. There is a difference sometimes drawn between "immune from" and "immune to." If $x$ is immune from $y$, then $x$ is exempt from $y$ or is not subject to $y$ because $x$ cannot be touched by $y$. By contrast, if $x$ is immune to $y$, then $x$ is resistant or impervious to $y$ because, although $y$ may touch $x, y$ has no effect on $x$ (see Garner 2003: 430). For example, whereas humans are immune from diseases that affect only birds, they can become immune to a given human disease if they get vaccinated either once or every few years. One may argue that logic, epistemic, and extreme psychological forms of insulation occur if first-order moral beliefs are immune from moral skepticism, whereas mild psychological insulation occurs if they are immune to it.

5 Both Burnyeat (1997: 112) and Bett (1993: 378, 380) maintain that Mackie (1977) is an insulator, although the former only quotes and examines a short passage in which Mackie does not actually endorse insulation, and the latter does not examine any of the relevant passages of Mackie's work.

6 Mackie $(1982: 246-247,251,254)$ reiterates that "value itself is a human and social product," and that the "invention of moral values" has made it possible for us to better live together, survive, and flourish.

7 Probably motivated by the healthy caution of any good systematic philosopher, Enoch (2011: 43 n. 51) remarks that he does not "do history, recent history included," and so he offers his suggestion because it is of independent interest, not because he believes it is a good interpretation of Mackie. By saying that he does not do history, what he means in this case is of course that he does not do exegesis, not even of not-so-distant twentieth-century authors. I wonder how such exegesis differs from interpreting the views defended in the latest article or book of a present-day philosopher with whom one will never be in contact.

8 See Joyce (2001: ch. 8; 2016b: 58-66; 2016c). Cf. Nolan et al. (2005). 
9 The alternatives are to do away with morality altogether (abolitionism or eliminativism), to both believe and promulgate belief in morality despite the evidence of its falsehood (conservationism, on which more below), and to hush up the evidence for moral error theory (what Joyce [2001: 214] calls "propagandism").

10 Joyce's moral fictionalism is of the revolutionary stripe because it recommends a radical change in one's attitude towards moral discourse once one becomes an error theorist. Mark Eli Kalderon (2005), in contrast, defends "hermeneutic" moral fictionalism, according to which ordinary people already adopt a makebelieve or fictive attitude towards moral discourse. (Nolan et al. [2005] call these two varieties of fictionalism "prescriptive" and "descriptive," respectively.) Hermeneutic fictionalism is a form of non-cognitivism, and a peculiar one at that, since it claims that, although moral sentences do express propositions that attribute moral properties to things or that represent putative moral facts, the acceptance of a moral sentence is not belief in the moral proposition expressed and the utterance of a moral sentence is not the assertion of the moral proposition expressed. The question of insulation does not arise for hermeneutic fictionalists, nor for traditional non-cognitivists: given that they contend that first-order moral claims do not express beliefs, it would make no sense for them to either affirm or deny that first-order moral beliefs are unaffected by moral skepticism.

11 Although he himself is a moral non-cognitivist, in the course of discussing moral error theory, Kalderon (2005: 103-105), too, seems to accept psychological insulation. For he holds that endorsing moral error theory does not entail that we should abandon, or suspend judgment about, first-order moral beliefs: it might be rationally permissible to continue to hold such beliefs either because $(i)$ it is psychologically impossible to stop holding them, or because (ii) it is socially beneficial to keep them. I interpret (i) as extreme psychological insulation and (ii) as mild psychological insulation (if there were pragmatic reasons for keeping first-order moral beliefs despite their falsity, it would be psychologically possible to do so).

12 Olson (2014: 196 n. 48) erroneously claims that his conservationism is similar to the view Cuneo and Christy (2011) call "propagandism"-actually, they call it "propagandism in the broad sense" because it is an expansive version of the view Joyce describes as propagandism (see note 9 above). For the propagandist in the broad sense takes up non-doxastic attitudes towards moral propositions (Cuneo \& Christy 2011: 94-95, 101). Conservationism seems to correspond to what they call “intransigentism" (Cuneo \& Christy 2011: 93). Olson's mistake is due to the fact that, just as the conservationist, the propagandist in the broad sense does not propose to transform ordinary moral discourse, but "to more or less leave things as they are" (Cuneo \& Christy 2011: 101). But note that the fictionalist does not propose to transform ordinary moral discourse either, but only recommends that those who have become moral error theorists adopt a fictive attitude when using first-order moral language.

13 I am grateful to Dale Chock, Hallvard Lillehammer, Nate King, and Aaron Zimmerman for their helpful suggestions and critical remarks.

\section{References}

Bett, R. 1993. "Scepticism and Everyday Attitudes in Ancient and Modern Philosophy," Metaphilosophy 24: 363-381.

Burgess, J. 2010. “Against Ethics.” In Joyce \& Kirchin 2010, 1-15.

Burnyeat, M. 1997 [1984]. "The Sceptic in His Place and Time.” In M. Burnyeat \& M. Frede (eds.), The Original Sceptics: A Controversy, 92-126. Indianapolis: Hackett. 


\section{Diego E. Machuca}

Cuneo, T. \& Christy, S. 2011. "The Myth of Moral Fictionalism.” In M. Brady (ed.), New Waves in Metaethics, 85-102. Basingstoke: Palgrave Macmillan.

Enoch, D. 2011. Taking Morality Seriously: A Defense of Robust Realism. Oxford: Oxford University Press.

Garner, B. 2003. Garner's Modern American Usage. Oxford: Oxford University Press.

Garner, R. 1994. Beyond Morality. Philadelphia: Temple University Press.

- 2010. “Abolishing Morality.” In Joyce \& Kirchin 2010, 217-233.

Hinckfuss, I. 1987. The Moral Society: Its Structure and Effects. Camberra: Australian National University.

Joyce, R. 2001. The Myth of Morality. Cambridge: Cambridge University Press.

- 2016a. Essays in Moral Skepticism. Oxford: Oxford University Press. 2016b. "Morality, Schmorality." In Joyce 2016a, 41-66. 2016c. "Moral Fictionalism." In Joyce 2016a, 219-239.

Joyce, R., \& Kirchin, S. (eds.). 2010. A World without Values: Essays on John Mackie's Moral Error Theory. Dordrecht: Springer.

Kalderon, M. 2005. Moral Fictionalism. Oxford: Oxford University Press.

Köhler, S. \& Ridge, M. 2013. "Revolutionary Expressivism,” Ratio 26: 428-449.

Mackie, J. L. 1977. Ethics: Inventing Right and Wrong. Harmondsworth: Penguin.

-1980. Hume's Moral Theory. London \& New York: Routledge. 1982. The Miracle of Theism. Oxford: Oxford University Press.

Marks, J. 2013. Ethics without Morals: A Defence of Amorality. New York: Routeldge.

Nolan, D., Restall, G., \& West, C. 2005. "Moral Fictionalism versus the Rest," Australasian Journal of Philosophy 83: 307-330.

Olson, J. 2014. Moral Error Theory: History, Critique, Defence. Oxford: Oxford University Press.

Sinnott-Armstrong, W. 2006. Moral Skepticisms. New York: Oxford University Press.

Wong, W. 2002. “The Problem of Insulation,” Philosophy 77: 349-373. 